\section{日本臨床外科学会三重県支部抄録 (第287回三重外科集談会)}

日 時：平成28年12月11日（日）午後 1 時より 会＼cjkstart場：ホテルグリーンパーク津 $6 \mathrm{~F}$ 葵・橘の間
1 潜在性乳癌と彰断されていたTis乳癌の一例 1. 三重大学乳腺センター

木本真緒 ${ }^{1}$ 今井余央 ${ }^{1}$ 長野真由 啮澤麻衣 $^{1}$ 野呂綾 $^{1}$

野原有起'伊藤みのり! 稲上警子' 花村典子' 小纵朋子!

64嵅女性。左腋窝腫瘤を主訴に前医受診。前医での左腋㸗LNのCNB で腺癌LN転移(Triple Negative(TN)) と診断。精查で全身に原発巣

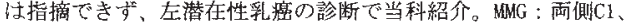

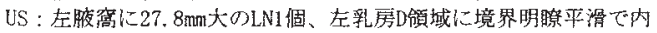
部均質な3m文の低エコ一腫瘤あり。薬剂アレルギー多数あり造影

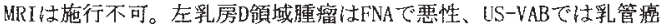
の診断で、異型の目立つ乳管上皮細胞の集簇を認め、前医でのしN DCNB標本と酷似していた。左乳㾴しN転移の診断で手術 $(\mathrm{Bt}+\mathrm{Ax})$ 施行。病理結果はpTisN1MO pStage2A。主睡瘤はUS-VABで严べて切 除されており手術標本内に腫瘍の残存なし。US-VAB標本で法腫場 の間質浸潤は明らかでなかったが、statusはLNOCNB標本と同に゙TN であり、同部からのし転移と考えられた。多数の薬凩アンルル゙ー 之甲状腺機能元進症、慢性心不全の既往歴老考虑し、術後は無治 療経過観察。術後8力月の現在無再発生存中。
3 十二指腸 GIST $D 1$ 例 1. 市立伊勢総合病院 外科・消化器外科

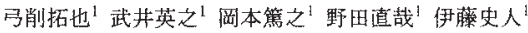

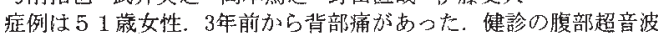
检呇で，“膵腫瘍の疑い”之指摘され，精查加療目的に紹介され た. $\mathrm{Hb} 8.0 \mathrm{~g} / \mathrm{dl}$ 之貧血を認め，腹部USでは右上腹部に約 $5 \mathrm{~cm}$ 大の pseudo-kidney sign 様のエコ一像を認めた。腹部造影CTで膵頭部

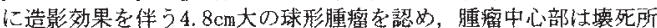
見を伴い，一部は十二指腸内腔と交通がみられた。 EGDでは十二指

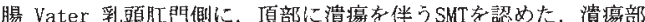
の生换で紡鍾形維胞の束状增殖を認めた，以上から，十二指腸寺 たは膵頭部発生の間葉系腫瑒之診断し,PPPDを行なった。摘出標 本の肉腿的所見任，十二指腸粘膜面に潰瘍形成を伴う，白色調充

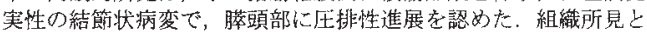
免疫染色結果から十二指腸 GIST 晾断し，高りスク群であるため 現在は Imatinib内服中である。本症例ではSMT溃瘍部分から腫煌 組織を採取し，術前診断できた。

4 绦後にstomach-partitior 腫の土例 1. 伊賀市立上野総合市民病院 西川隆太郎 ${ }^{1}$ 奥川喜永' 森本雄費 ${ }^{1}$ 横江顽 ${ }^{1}$ 由中光司 ${ }^{1}$ 浦田久志 ${ }^{1}$ 三本潖雄 症例は74歳男性。平成28年9月某日，上腹部違和感を主詐に，近医 で手拳大の上腹部腫瘤を指摘され，当院へ紹介となった，腹部CT

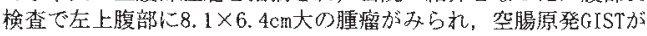
疑われたが，上部消化管造影検雀では，十二指腸4th portionを基 部としていた，手衔所見では，腫瘍はSMAの左側で，十二指腸4th portion 基部として，空腸間膜内背側寄りに壁外発育してい た，てりため，第1から第 3 空腸動脈老切離 $\mathrm{L} ，+二$ 二指晹 $3 \mathrm{rd}$ portionから空腸起始部 $70 \mathrm{~cm}$ 合併切除寸ることで，腫海を切除し えた。再建では，空腸断端と十二指腸2nd portionと老僋々肠合 し、更にそこに, stomach- partitioning gastrojejunostomy 併設した。手術特間は2時間58分, 出血量は112mlであった。術後 経過は順調で，術後17日目に合併症無く退院となった。病理組織 診断は，平滑筋腫であった，今回の再建法は，術後合併症のリス ク奔軽減しうる新たな再建法であり，報告する。

\section{5} 1. 是立医療センター 外科

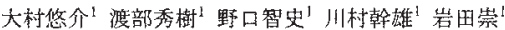

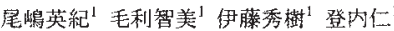

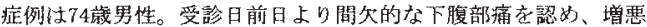
したため近医受診された。近医での精査の結果、S状結腸に通過障 害を認当院への紹介となった。当院てのCTでもS状結腸に通過障 害、造影剂果不良領域齐認めた。S状結腸捻転の診断て内視鏡的整 復索試みるす整復困難であり当科に紹介となり祭急試験關腹術を 施行した。開腹するよ下行結晹が大網裂孔に嵌頓しており、脽膜 のうつ血老認めた。嵌頓解除後它晹管の色謂の回復は認めず、同 部を㚬除し、横行結腸人工肛門妾造設した。摘出標本の䊀膜面は 黑く変色しており甥死を認め、強い虚血性変化があったことを示 唆していた。街淩経過は良好であり、術後25日目で退院とした。 大網裂孔へルニアは大網裂隚に腸管が嵌入することによって生じ る内へルニアのIつであり稀な病態である。下行結腸が嵌入してい る症例俚さらに稀であり、若干の文献的考察老加之て報告する。 
6

バリウム虫垂资の 1 例

1. 若葉病院 外科, 2 . 三重大学消化管小児外科

市川崇 ${ }^{!}$三枝晋 $^{1}$ 大井正貴 ${ }^{2}$ 井上靖浩 ${ }^{2}$ 油哲 ${ }^{1}$

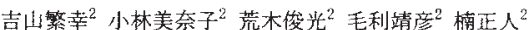

症例は41藏男性. 発热, 下腹部痛を主訴に当院救念搬送. 来院時 理学所見上, 反跳痛, 筋性防御を認め, 急性腹膜炎之診断した。 腹部X線検查では右下腹部に約 $1.5 \mathrm{~cm}$ 大の不透過体を認めた。腹部 CTでは，不透過体は10000HUを超えるCr值及びStrong art ifact t 伴い，回腸末端部の浮腫，腹水を認め，金属異物による穿孔，腹 膜炎を疑った，急性腹膜炎の診断で緊急手術老施行した，開腹所 見は澧性腹水を中等量認め，蜂穽織资性虫垂炎被覆敫孔であった。 虫垂切除術を施行し，術後経過は良好であった。術後，1か月前に 胃検診のためバリウム検查を施行していたことが判明した。 バリ ウム虫垂焱は比較的まれな疾患であるが，右下腹部に不透過体を 認好埸合，バリウム出垂炎老考虑し，バリウム検査の病歷聴炆 が術前早期診断に重要であると考えられた。バリウム虫垂炎の一 例を経験したので，若千の文献的考察老加え燨告する。
9 周術期管理に困難を極めた規格外の高BMI患者の1例 1. 伊勢赤十字病院 外科

传藤啓太 ${ }^{1}$ 藤井幸治 ${ }^{1}$ 伊藤拓也 赤尾希美 $^{1}$ 中川芳希!

坂口充弘 ${ }^{1}$ 堂本佳典 ${ }^{1}$ 由村佳久 ${ }^{1}$ 熊本幸司 ${ }^{1}$ 松本英一!

高橋幸二 ${ }^{1}$ 宮原成樹 ${ }^{1}$ 楠的司 ${ }^{1}$

直近30年間で、BMI25以上の日本人男性は1.5倍に增加して扝り、 日常診療でも肥满患者走治療することは多い。症例は36歳男性。 $163 \mathrm{~cm} 、 180 \mathrm{~kg} 、 B M I 60.1$ 。右下腹部痛で来院し、S状結腸癌、小腸 間膜内への限局性腹膜炎と診断した。術前の手術体位シミュレー ションと特注器具を海備して碎石位で開腹S状結腸切除術、小晹部 分切除術を施行。手術時間4時間46分。出夏量 $500 \mathrm{~m} 1$ 。閉創仕 Smead-Jones縑合によるretentionに加えてネラトンカテーテルを 用いたBolster変法で行い良好な経過を得た。病理結果は pStage =bであり術㖟補助化学療法在計画した。CVポートは上腕 に作成した。体表面積2.6と高犆であるも、ASCOの肥满患者に対扵 る化学療法の適正投与量についての臨床ガイドラインを参考に決 定した。経過において様々な工夫老要としたため報告する。
7 1. 三重中央医㬌センター

松田明敏 ${ }^{1}$ 信岡祐 ${ }^{2}$ 湯溚浩行! 谷川寛自 ${ }^{1}$ 横井一!

患者は22歳女性。来院2週間前加ら心窝部湧を癹め、来䛷前日に痛 みが急激に増强、下腹部痛となり前医を受診。CTにて虫華の著明 な肥大を認め、当院紹介。

来院時、右下腹部に圧痛、軽度反跳痛老認め大。体温 $37.1^{\circ} \mathrm{C}$ て WBC：8920、CRP：2.71。CEA、CA19-91基準値内。CTで虫垂蛙 38 m七腫大し、粘膜の肥厚がタられたが、造影効果は先端部を除 き强くなく、炎症性変化として典型的でなかつた。破裂の恐れも あるため、同日虫垂腫瘤の疑いで腹腔鏡下手術を施行。虫垂は著 明に腫大し小腸間膜と强固に魔着、回查部からsurgical trunk近 傍までのリンパ節腫大を認め、これを敦清し右結晹切除を行つ た。

病理开見では虫垂全尿に高度の楾維性、浮腫性肥捍、好酸球者含 んだ炎症細胞浸潤が兒られ、肉芽腫性変化はなく、診断基準を满 たさないがクローン病が疑われた。

術後経過は良好で、術後12日目に退院。退院後上部、下部内視鏡 を行ったが少ローン病を疑う所見は得られなかった。

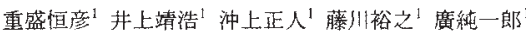

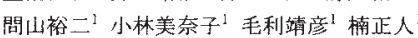

症例は初診時35歲女性。腹部膨渶感を主訴比近医を受衫、多量腹

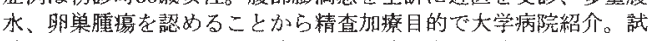
驗開腹にて、禹側附属器切除、虫垂切除、大網切除、回腸人工肛 門造設街老施行、病理診断で虫垂粘液腺癌腹膜播種と診断され た。治癒切除不能のため、mFOLFOX6+ババシズマブ療法で病勢コン トロール後、初回手術後5ヶ月目に、再度減䡒手術（大晹严全摘、 脾摘、瞙尾部切除、播種切除) およひひ腹腔内温熱化学療法 (HIPEC) を施行した。朋門部〜胃の鱕種巣は切除不能で、PCI 24、CCR 3で 市った。以後、全身化学療法を継繶し、減量術後 1 年 2 ヶ月目に、 再度減量手衡（異全摘、子宮全摘、小腸部分切除）が施行された (PCI 33、CCR 3)。初診加52年4か月旺在、PS1で外来通院中で あり、3回目の減量手術+HIPECが予定されている。
10 腸重積を発症した青黛治療中㵋瘍性大腸资の1例

1. 三重大学大学院 消化管・小览外科

山本晃 ${ }^{1}$ 近藤哲 ${ }^{1}$ 大北喜基 ${ }^{1}$ 荒木俊光 ${ }^{1}$ 吉山繁幸

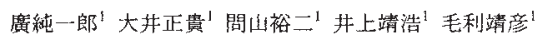

棹正人 ${ }^{1}$

症例《43藏女性。35藏時に潰場性大腸资之診断され、当科で内科 的治療を継続していたが、ステロイド依存性で、再然、筧解を繰 り返していた。漢方薬である青黛在细人的に購入し、内服したと ころ、劇的な症状の改善を認め、晛解導入された。しふし、内服 閶始から2か月が経過したところで突然の右下腹部㴼索生し、救急 搬送された。腹部超音波および腹部门検查より晹重積と診断さ れ、回盲部切除崔が施行された。 古くから中国で生薬として使用されている青黛だが、近年、潰㿋 性大腸炎に対する有效性が報告されている。本症例注强い腸管照 の浮腫を菤起したことにより腸重積になったと考えられ、文献的 考察を加え、報告する。

11 転移の 1 例 1. 㻌鹿中央総合病院外科 大森隆夫 服部可奈 $^{-}$市川健 ${ }^{1}$ 草墚智樹 $^{1}$ 大倉康生 ${ }^{1}$ 濱田蜸会! ${ }^{1}$ 田网大樹! 症例：55歳女性。現病歴：近医より両葉に多発肝転移を伴う、不 完全閉塞直腸煰にて当院紹介となった。血液梌查 : $\mathrm{Hb} 8.5 \mathrm{~g} / \mathrm{d}$ 、 CEA $12.0 \mathrm{ng} / \mathrm{m} 1 、 C A 19-9131 \mathrm{~V} / \mathrm{m} 1$ 。画像診断：多数の中間りンハ

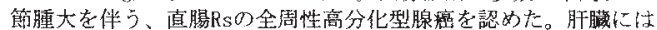
S3に1個と、S6-7に最大径 $4 \mathrm{~cm}$ の1個在含む右菜に6個の転移巣老認

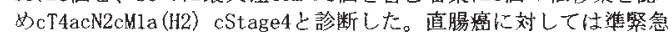
手術、肝に対しては諳画的二期的肝切除老選抧し、初回手術とし てD3リンパ節郭清党伴5高位前方切除術に加之肝S3部分切除兼門 脈在枝離断術を施行した。術淩合併症はなく、9 日目に一時退院し た。残存予定肝容量の增大と、新たにB1に肝転移紧を磪認した。

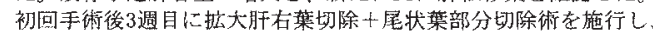
術中エコーで遺残肝転移のないこと老確認した。断端は陰性、RO 手術之なった。2回目手術10日聁に退院、術後補助化学璙法学予定 している。 
奥村西純 ${ }^{1}$ 加藤弘幸 ${ }^{1}$ 金兒博司 $^{1}$ 出崎良輔 $^{1}$ 西井菓彦 $^{2}$ 症例は56歳、女性。背部痛、胸姪けを主訴に近医を受診した。単 純CTにて睟管㹡張と膵腫大を指摘され当科紹介受診となった。 造影 C Tで脺体部に門脈・腹腔動脈に接する造影效果の乏しい腫

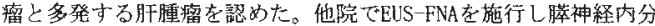
泌癌（以下P-NEC）と診断された。国立がん研究センタ一中央病院に セカンドオピニオン受診し、三重大学病院腫㻛内科にて肺小細胞 癌に準じた化学療法(シスプラチンーエトポシド)を4コース実施す るむ副作用強く治㙩中断上なった。初診時上り6ヶ月経過した現 在、局所進行と転移巣の增恚を認好ている。背部痛コントロール 目的で当院通院中である。

膵神経内分泌癌は稀な疾患であり多発転移を伴う場合、手術適论 はなく確立された化学療法梳存在しない。今回多発肝転移老伴う P-NECの1例老経験したので文献的考察を加えて银告する。
15 行した 1 例

1. 済生会松阪外科

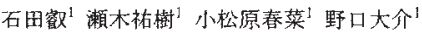

河埜道垁 ${ }^{1}$ 近藤昭信 ${ }^{1}$ 田中秷 ${ }^{1}$ 長沼澾史

患者は52筬男性。当院泌尿器科にて 2005 年左腎細胞痕で左㛑摘出 術施行。2009年肺転移（4ヶ所）にて肺部分切除術施行。2010年肺 転移再発にてRFA施行。その後残存寸る肺転移に対してIFN- $\alpha$ 投与 療法、スニチニブ内服治療を行っていたが、2014年12吕閉塞性黄 㾞にて当院入院。閉塞性黄痘の原因として造影CTにて膵頭部に $24 \mathrm{mn} 大 の$ 不均一に早期に強く造影される腫瘍を認め、膵尾部にも

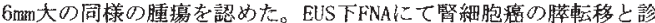
断された。膵以外には肺転移があるものの、増大傾问が吾しいた め手術目的に外科紹介となり、2014年2月に中央区域温存膵切除術 を施行した。術後䏽液瘦索併発するも街後87日自に退院。退院後 は泌尿器科にてエベロリムス内服治療となった。その後新たに脳 転移の出現あるも $y$ ナイフを施行し、玩在も外来通院加釉中であ る。

16 脺頭十二指腸切除捘のドレーン長期留置が原因と考 えられる膵空腸吻合部膵液瘦に対し緊急で膵胃吻合を施行した1例 1. 三重大学肝胆膵・移植外科

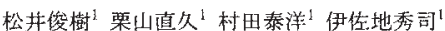
術後ドレーン留置は感染性合併症予防の観点加ら早期拔去怔推奖 されている。症例は86藏男性。門脈浸埾を伴う脺頭部煰に对し， NCRT後にSSPPD (Child変法再建) 老施行。膵㹥萎縮硬化L，主搭 管径は8m正，膵空腸粘膜勄合はno stentでpair watch suturing technique で施行した．ドレーン先端は膵空腸吻合部近傍に留置し た.POD1，3，6亿提出したドレーン排液中再推は低值で，ドレー ン拔去を検討したが，拔去予定日にドレーン排液量が急增したた めドレーン抜去老媱期した。 多量の腹水流出が続き，ドレーン留 置を継続したところ，POD12にドレーン排液の性状が変化し，Amy 值は800000/L超で连発性腆液瘦々診断した。造影CTで明らかな伋 性動脈瘤は認めなかったが，血性排液が繶き，仮性動㟲瘤切迫破 裂を疑い，POD33に緊急で膵空晹吻合部を離断し，嵌入法で胃膵 再吻合を施行した。 ドレーンの長期留置上留置位置が原因で，荤発 性膵液瘻を発症させた可能性がある。

17 術前加療中、胃に浸润穿破したUR-LA膵尾部癌の1切

除例

1. 松服中央釉合病院外科

野村綾香 ${ }^{1}$ 田端正已 $2^{1}$ 阪本達也 藤村侑 $^{1}$ 前田光贵 ${ }^{1}$

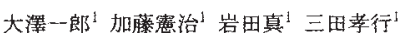

諚例は70歳男性。体重城少, 心窝部違和感にて当院を紹介さ机た。

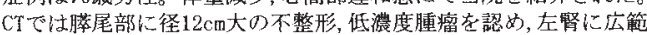
に浸罣し胃後壁女医排していた。また腫瘤加連続して大動眽左 半调に至る軟部隍影が存在し, 左㫮動・静眼は軟部陰影内に埋没し ていた。EUS-FNAで腺癌が証明され，大動脈浸洞を伴うUR-LA膵尾部

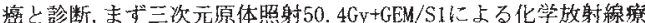
法を施行した。しかし加撩後も堙堭に著変なく, GEM+nab-PTXを2 コ一ス追加守ることとした。1コース終了後、炎症反応加上昇し

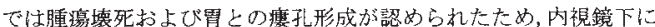
debridement行った。炎症消退待って脾合併膵体尾部切除十置

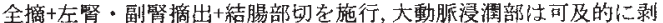
漓隹し, 左腎動脈は根部で, 左腎静脈はSMA背側で切離した。術後59日 目からGEM+nab-PTX投与を開始したが, 71 日目, 多発腷梗塞学発症, 現在右片麻瘦に対しリハビリ施行中で女る。 
18 膵頭十二指腸切除術後急性期に登症した䍁㤦塞に対 し、迅速な対応にて血管内治療が奏功した一例

1. 三重大学医学部附属病院肝胆膵移植外科

武内泰司郎 ${ }^{1}$ 村田泰洋 ${ }^{1}$ 飯澤祐介 ${ }^{1}$ 栗山直久 ${ }^{\prime}$ 水野修吾!

櫻井洋至 ${ }^{1}$ 伊坔地秀司 1

症例は67歳男性。腹部大動脈瘤人工血管置挺術、慢性心房細動の 既往があり、トロンビン阻害剂内服治療中であった。膵頭部膵管 内乳頭粘液性腫㻛に対して、術前にダビガトラン内服を中止し、 严全累温存膵頭十二指腸切除術を施行した。術後 2 日目に低分子人 パリンの皮下注射を開始した。術㣪4日目に突然の左上下肢不全麻

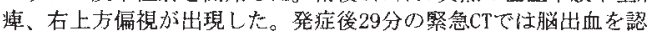
めず、脳梗塞が疑われ、発症後52分の頭部MRAにて右中大譄動脈 (MCA) の途絶、DHIにて右MCA領城の高信号を認女た。血栓塞栓性 急性脳梗塞の診断にて発症加588分後に腷神経外科に上万緊急血 管内治療加開始された。血栓除去により登症から109分後に再開通

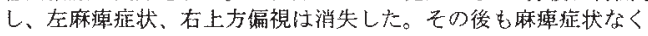
步行も可能となり链後30日目に退院となった。院内発症の急性期 脳梗塞に对しては、stroke call、院内チームムの迅速な連携により 不可逆的核経逜を防くことが可能である。 